\section{BRS 425: the first runner peanut cultivar related to wild ancestral species}

\author{
Taís de Moraes Falleiro Suassuna ${ }^{1^{*}}$, Nelson Dias Suassuna ${ }^{1}$, \\ Júlio César Bogiani ${ }^{1}$, Fabiano Perina ${ }^{1}$, Daniel de Brito Fragoso ${ }^{2}$, \\ Valdinei Sofiatti ${ }^{1}$, Everaldo Paulo de Medeiros ${ }^{1}$, Márcio de \\ Carvalho Moretzsohn ${ }^{3}$, Soraya Cristina de Macedo Leal- \\ Bertioli ${ }^{4}$, David John Bertioli ${ }^{4}$, Jair Heuert ${ }^{1}$, Hildeu Ferreira \\ Assunção ${ }^{5}$, Luiz Alberto Colnago $0^{6}$, Tarcísio Marcos de \\ Souza Gondim ${ }^{1}$, Ramon Araújo Vasconcellos ${ }^{1}$, José Ernani \\ Schwengber ${ }^{7}$ and José Renato Cortes Bezerra ${ }^{1}$
}

\begin{abstract}
BRS 425 is a high-oleic runner peanut cultivar related to wild ancestral parents, partially resistant to early and late leaf spot and spotted wilt. It is large-seeded and contains $46 \%$ oil. BRS 425 is adapted to the main peanutproducing regions of Brazil.
\end{abstract}

Keywords: Arachis hypogaea, A. ipaënsis, A. duranensis, disease resistance, tetraploid route.

\section{INTRODUCTION}

In Brazil, peanut (Arachis hypogaea L.) has become an important crop, with successively increasing yield and quality over the last 20 years. Four major peanut types are cultivated: Runner, Valencia, Virginia and Spanish. Of these, the runner type has been improved for yield, uniform maturity, pod and seed shape and size, and tested for processing quality and sensory traits; its decumbent growth habit is well suited for mechanical harvesting. The preference of Brazilian peanut producers for the runner type has intensified the implementation of modern cultivation and post-harvest technologies, eventually increasing the country's participation in the national and international highly demanding peanut market (Sampaio 2016).

The peanut market is profitable and requires cultivars with a high oleic acid content, extending the shelf life of peanut-based foods. This trait is common in peanut cultivars released in Brazil since 2012 (Godoy et al. 2017). On the other hand, most of the recently released cultivars are susceptible to early leaf spot, caused by Passalora arachidicola (Hori) U. Braun (teleomorph: Mycosphaerella arachidis Deighton), late leaf spot, caused by Passalora personata (Berk. and M.A. Curtis) S.A. Khan \& M. Kamal (teleomorph: Mycosphaerella berkeleyi W.A. Jenkins), and spotted wilt, a thrips-transmitted virus caused by different species of the genus Tospovirus (Camelo-Garcia et al. 2014, Suassuna et al. 2016).

The research progress over the last years has advanced the understanding of the origin of cultivated peanut. This allotetraploid crop (with an AABB genome)
Crop Breeding and Applied Biotechnology 19:3, 373-377, 2019 Brazilian Society of Plant Breeding. Printed in Brazil http://dx.doi.org/10.1590/198470332019v19n3c52
${ }^{*}$ Corresponding author:
E-mail: tais.suassuna@embrapa.br
(D) ORCID: 0000-0002-6360-5168

Received: 08 January 2019 Accepted: 06 April 2019

\footnotetext{
${ }^{1}$ Embrapa Algodão, Rua Oswaldo Cruz, Centenário, Campina Grande, 58.428-095,
}

PB, Brazil

${ }^{2}$ Embrapa Arroz e Feijão, 75.375-000, Santo Antônio de Goiás, GO, Brazil ${ }^{3}$ Embrapa Recursos Genéticos e Biotecnologia Parque Estação Biológica, Brasília, 70.770-

917, DF, Brazil

${ }^{4}$ University of Georgia, Center for Applied Genetic Technologies, Athens, GA, 30.602-6810, United States of America

${ }^{5}$ Universidade Federal de Goiás, 75.801-615, Goiânia, GO, Brazil

${ }^{6}$ Embrapa Instrumentação, 13.560-970, São Carlos, SP, Brazil

${ }^{7}$ Embrapa Clima Temperado, 96.115-000, Pelotas, RS, Brazil 
is native to the lowlands of northwestern Argentina and southeastern Bolivia and has the putative ancestral species A. ipaënsis (BB) and A. duranensis (AA) (Bertioli et al. 2016). The development of a synthetic polyploid by colchicine doubling, combining $A$. duranensis and $A$. ipaënsis (Fávero et al. 2006) led to the generation of interspecific populations with variability for agronomic traits and resistance to leaf spots in Spanish peanut genotypes, in Senegal (Fonceka et al. 2012) and in a Runner peanut genotype in Brazil (Suassuna et al. 2015, Leal-Bertioli et al. 2018). These results reinforce the value of using wild species in peanut breeding particularly of wild ancestral parents, for peanut breeding programs. As a result, six early (90-day cycle) Spanish cultivars related to the wild parents were developed and released in Senegal, with moderate resistance to early leaf spot, diverging from the recurrent parent, cultivar Fleur 11, which is susceptible (Dr. Issa Faye/ISRA, personal communication).

In a $\mathrm{BC}_{1}$ Runner IAC $886 \times$ [A. ipaënsis $\times$ A. duranensis] $]^{4 \times}$ population, a partially leaf spot-resistant segregating line was selected (Suassuna et al. 2015) and crossed with high-oleic cultivars to generate new breeding populations. Using conventional breeding methods of selection for yield, pod and seed shape and size, high-oleic acid content and partial resistance to foliar diseases, we developed the first runner cultivar related with wild ancestral species of peanut.

\section{GENETIC ORIGIN AND DEVELOPMENT}

The peanut cultivar BRS 425 is related to wild ancestors through its male parent, the advanced line LPM 17-A (Figure 1), selected from the $B C_{1}$ Runner IAC $886 \times$ (A. ipaënsis $\times$ A. duranensis) ${ }^{4 \times}$ progeny LPM 17 (Suassuna et al. 2015). The leaf spot resistance of LPM 17-A is higher than the recurrent parent, it has yellow flowers, a large seed size (100-seed weight $=84 \mathrm{~g}$ ) and tan seed coat. The female parent was cultivar 'IAC 505', donor of the high-oleic acid trait.

By the pedigree method, in the 2012/2013 growing season, in Santo Antônio de Goiás - GO, plant '256' was selected from the segregating $F_{2}$ population. The progenies $\left(F_{3}\right)$ of the selected plant (2013-256) were evaluated in the second growing seasons of 2013 under irrigated conditions. From this progeny, plant ' 425 ' was selected, and the preliminary line 2013-425 $\left(F_{4}\right)$ was subjected to evaluations in the main growing season of $2014 / 15$. The plants in the $F_{2}-F_{3}$ generations were selected for decumbent growth habit, pod shape, seed size and seed coat color to develop runner market a type

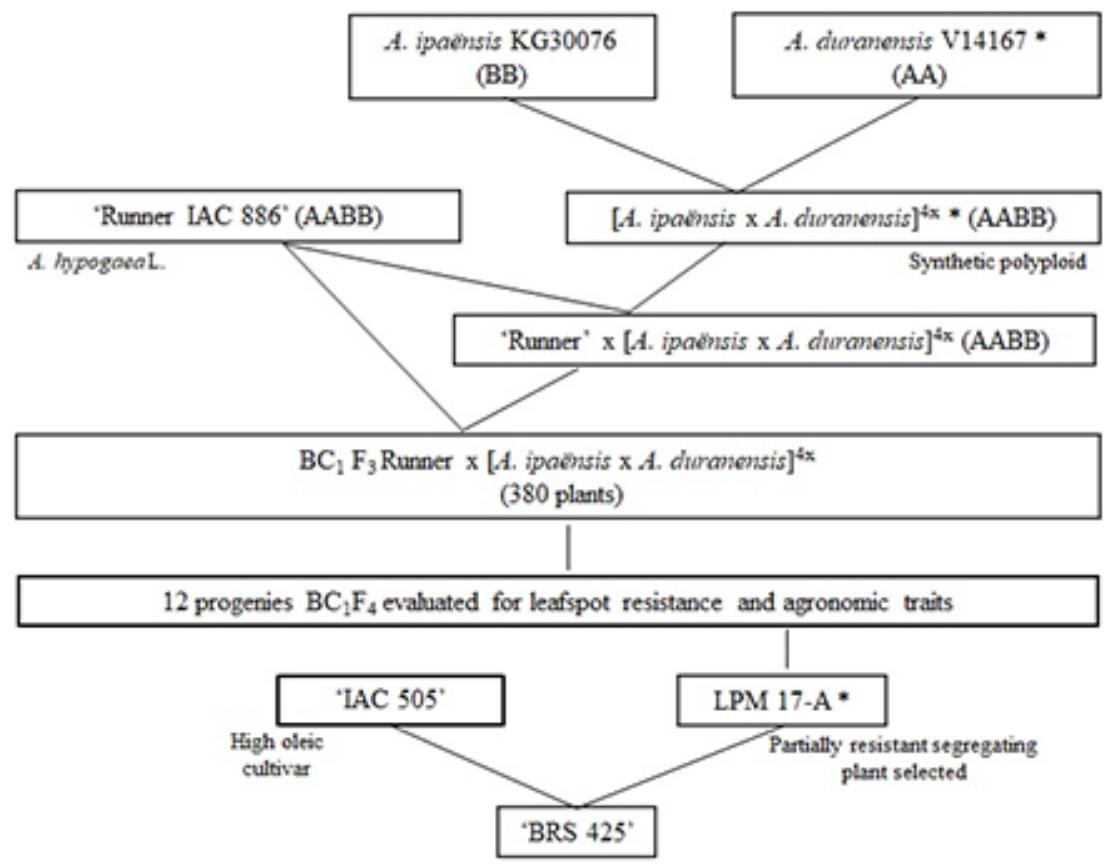

Figure 1. Pedigree of BRS 425, showing the tetraploid route (the synthetic polyploid is derived from the wild ancestrals of peanut, $A$. ipaënsis and $A$. duranensis). * yellow flower, a morphological marker inherited from $A$. duranensis, observed in LPM 17-A, the male parent of BRS 425 . 
with a high-oleic acid content (> 70\%). In the $\mathrm{F}_{4}$ generation, line 2013-425 was selected in trials with and without fungicide spraying. Oil and oleic acid content were assessed in the $F_{3}$ and $F_{4}$ generations by Near Infrared (NIR) equipment, as described by Suassuna et al. (2015), at Embrapa Cotton. Using the NIR, oil and oleic acid content were assessed in the $\mathrm{F}_{5}$ generation by nuclear magnetic resonance (NMR), at Embrapa Instrumentation. A sample of breeder seed was also evaluated by gas chromatography for oil content and composition.

\section{TRAIT PERFORMANCE}

Cultivar BRS 425 was evaluated in the main growing seasons of 2015/2016, 2016/2017, and 2017/2018, resulting in a total of 20 field trials. In the 2015/16 growing season, the cultivar performance was tested (Table 1) at five locations: Santo Antônio de Goiás - GO, Bela Vista - GO, Hidrolândia - GO, Jataí - GO, and Pelotas - RS. In the 2016-17 growing season (Table 1), BRS 425 was tested at six locations: Herculândia - SP, Jaboticabal - SP, Santo Antônio de Goiás - GO, Cristianópolis - GO, Palmas - TO, and Petrolândia - PE; and in 2017-18 (Table 2), at nine locations: Tupã - SP, Frutal - MG, Palmas - TO, Luís Eduardo Magalhães - BA, Primavera do Leste - MT, Jataí - GO, Santo Antônio do Leste - MT, Barbalha - CE, and Santo Antônio de Goiás - GO.

Pod yield $\left(\mathrm{kg} \mathrm{ha}^{-1}\right)$ was evaluated across all locations. Software Selegen-Reml/Blup was used for Restricted Maximum Likelihood/Best Linear Unbiased Prediction (REML/BLUP) analysis (Resende 2016). The genotypes (BRS 425 and the commercial checks) were ranked, based on the genotypic values of all individual trials and on a combined analysis involving all locations (Resende and Duarte 2007). Cultivar BRS 425 was ranked as the highest-yielding genotype at the locations where the disease management using fungicides (leaf spots) or thrips control with insecticides was inefficient or not applied (e.g., in trials with: high leaf spot severity, as observed in Santo Antônio de Goiás - GO in 2016/17; severe spotted wilt and leaf spot epidemics in Herculândia - SP 2016/17; no chemical management in Jataí - GO and Pelotas - RS 2015-16, Palmas - TO 2016-17; Table 1). 'BRS 425' was also evaluated under optimum management conditions, ranking among the highest yielding genotypes (Table 2). In the 2017/18 trials, BRS 425 produced the highest pod yield in Frutal - MG (6825.0 kg ha-1) and in Luís Eduardo Magalhães - BA (7440.8 kg ha-1), and yield performance was highest in Primavera do Leste $-\mathrm{MT}\left(8131.3 \mathrm{~kg} \mathrm{ha}^{-1}\right)$, indicating a yield potential of $>8000 \mathrm{~kg} \mathrm{ha}^{-1}$. Across all 20 trials, the mean genotypic value for pod yield of BRS 425 was $4987 \mathrm{~kg} \mathrm{ha}^{-1}$, exceeding the checks IAC 503 (4692 kg ha-1), IAC OL-3 (4520

Table 1. Genotypic value (GV) of peanut pod yield $\left(\mathrm{kg} \mathrm{ha}^{-1}\right)$ and ranking (Rank) of the cultivars obtained by the REM/BLUP methodology in 11 performance tests in the 2015-16 and 2016-17 growing seasons

\begin{tabular}{|c|c|c|c|c|c|c|c|}
\hline \multicolumn{4}{|c|}{ 2015-2016 growing season } & \multicolumn{4}{|c|}{ 2016-2017 growing season } \\
\hline Location & Cultivar & GV & Rank & Location & Cultivar & GV & Rank \\
\hline \multirow{3}{*}{$\begin{array}{l}\text { Santo Antônio de Goiás } \\
\text { - GO }\end{array}$} & BRS 425 & 6769.0 & 2 & \multirow{4}{*}{$\begin{array}{l}\text { Santo Antônio de } \\
\text { Goiás - GO }\end{array}$} & BRS 425 & 5361.9 & 1 \\
\hline & Runner IAC 886 & 6296.0 & 8 & & IAC 503 & 4575.5 & 7 \\
\hline & IAC 505 & 6205.6 & 9 & & IAC OL-3 & 4492.0 & 8 \\
\hline \multirow[b]{2}{*}{ Hidrolândia - GO } & BRS 425 & 4963.0 & 2 & & Granoleico & 4415.1 & 9 \\
\hline & IAC 503 & 4646.7 & 7 & \multirow{2}{*}{ Herculândia - SP } & BRS 425 & 5297.4 & 1 \\
\hline \multirow{3}{*}{ Bela Vista de Goiás - GO } & IAC 505 & 3229.8 & 3 & & Granoleico & 4840.3 & 8 \\
\hline & BRS 425 & 3157.6 & 5 & \multirow{4}{*}{ Cristianópolis - GO } & BRS 425 & 6250.7 & 3 \\
\hline & IAC 503 & 3013.6 & 9 & & IAC 503 & 5979.8 & 5 \\
\hline \multirow{3}{*}{ Jataí - GO } & BRS 425 & 3530.3 & 1 & & IAC OL-3 & 5568.8 & 8 \\
\hline & IAC 505 & 3350.3 & 4 & & Granoleico & 5432.3 & 9 \\
\hline & Runner IAC 886 & 3106.8 & 8 & Jaboticabal - SP & IAC OL-3 & 7153.4 & 1 \\
\hline Pelotas - RS & IAC 505 & 1133.9 & 10 & \multirow{4}{*}{ Palmas - TO } & BRS 425 & 2138.3 & 1 \\
\hline \multirow{4}{*}{ Petrolândia-PE } & IAC 503 & 5819.9 & 2 & & Granoleico & 1972.4 & 4 \\
\hline & IAC OL-3 & 5790.2 & 5 & & IAC 503 & 1940.8 & 5 \\
\hline & BRS 425 & 5763.3 & 6 & & IAC OL-3 & 1916.7 & 6 \\
\hline & Granoleico & 5645.5 & 9 & & & & \\
\hline
\end{tabular}


Table 2. Genotypic value (GV) of peanut pod yield $\left(\mathrm{kg} \mathrm{ha}^{-1}\right)$ and ranking (Rank) of the cultivars obtained by the REM/BLUP methodology in nine performance tests in the 2017-18 growing season

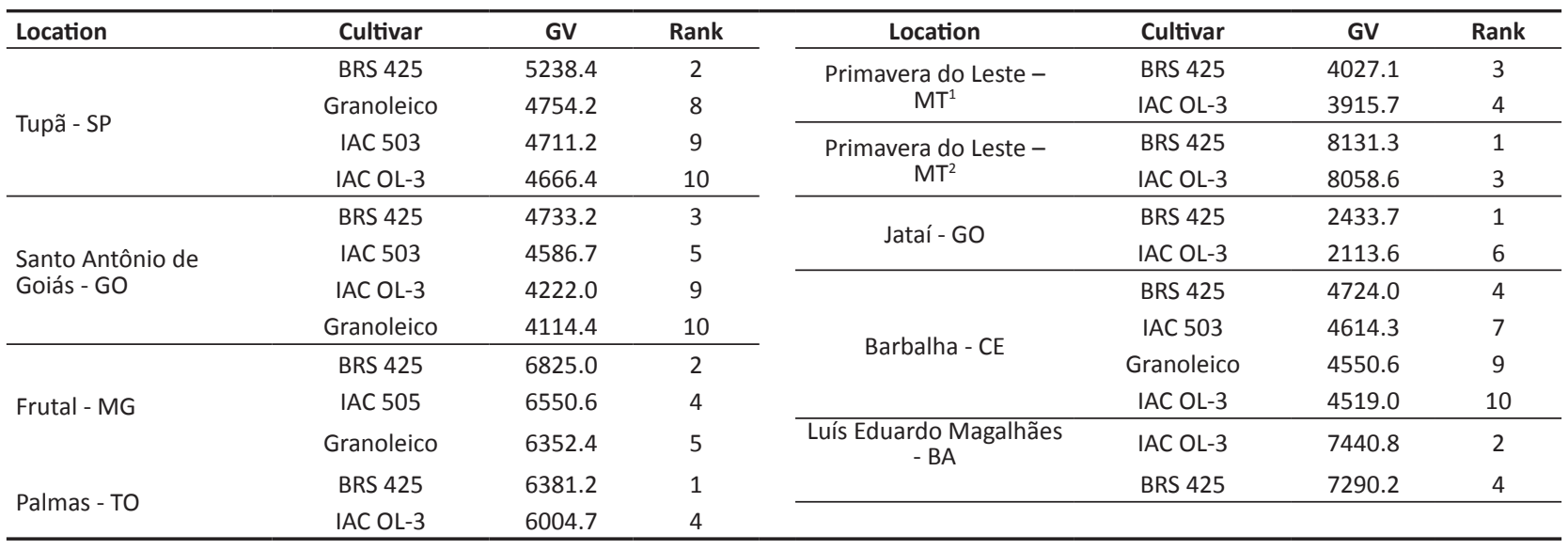

${ }^{1}$ Second growth season, late planting; ${ }^{2}$ Main growth season, early planting.

kg ha-1), IAC 505 (4451 kg ha-1), and Granoleico (4271 kg $\left.\mathrm{ha}^{-1}\right)$, with an accuracy of 0.82 and $\mathrm{CV}$ of 17.7.

In Santo Antônio de Goiás, GO (lat 16 30.2' S, long 49응 $17.2^{\prime} \mathrm{W}$, alt $823 \mathrm{~m}$ asl), cultivar BRS-425 has an alternate branching pattern and decumbent growth habit; the main stem is not apparent. Flowers are orange, the seed coat light tan and the kernels were classified as large runner type, with a mean 100-seed weight of $75.8 \mathrm{~g}$. (ranging from 74.0 to $77.4 \mathrm{~g}$ ) and a seed/pod weight ratio of $76 \%$. The cultivar has a medium cycle length and is indicated for the Central-Southeast region (135 days). However, when grown at higher latitudes, e.g., in the Northeast region, it can reach maturity at 125 days after planting. The total oil content $(46 \%)$ and fatty acid composition ( $81.2 \%$ of oleic acid) meet the Brazilian market requirements (Table 3 ).
Table 3. 'BRS 425 ' oil content and composition determined by gas chromatography

\begin{tabular}{lc}
\hline Fatty acid & Content (\%) \\
\hline Palmitic acid (C16:0) & 6.15 \\
Margaric acid (C17:0) & 0.10 \\
Heptadecanoic acid (C17:1 cis-10) & 0.07 \\
Stearic acid (C18:0) & 2.56 \\
Oleic acid (C18:1 cis-9) & 81.2 \\
Linoleic acid (C18:2 cis-9-12) & 2.27 \\
Arachidic acid (C20:0) & 1.34 \\
Eicosenoic acid (C20:1 cis-9) & 1.71 \\
Behenic acid (C22:0) & 2.80 \\
Erucic acid (C22:1 cis-9) & 0.13 \\
Lignoceric acid (C24:0) & 1.46 \\
\hline Total fatty acid & 46.00 \\
\hline
\end{tabular}

'BRS 425' is a medium cycle high-oleic acid runner cultivar, with high yield and partial resistance/tolerance to the main foliar diseases of peanut (leaf spots and spotted wilt) in Brazil. It is a high-yielding runner peanut cultivar for optimum environments but can also be recommended for low input farming or under higher disease pressure.

\section{SEED MAINTENANCE AND DISTRIBUTION}

BRS 425 was catalogued (no. 37303) by the Brazilian Ministry of Agriculture, Livestock and Food Supply. Foundation seed is produced by the Secretariat of Innovation and Business (SIN) of Embrapa, in partnership with peanut seed companies, to produce certified seed.

\section{ACKNOWLEDGEMENTS}

The authors thank for partnership in field trials: the students Kennedy Brunno de Brito Martins, Lucas Correia Costa, Ramon Guedes Matos, Eloene Rodrigues Godoy and Jorge Luis Souza Ferreira; Rafael Matos (Goiás state); Romildo Contelli, Nilson Contelli, Pablo Rivera and Rodolfo Pires Ribeiro (Beatrice Peanuts, west region of São Paulo state); Walter Souza, José Antônio de Souza Rossato Jr., Guilherme Salis Uitdewilligen, Talita Reisch and Natália Buzinaro Caporusso (Coplana, northwest of São Paulo state); Marco Aurélio Campos and Marcos Guido Domenici (Frutal/MG), Cristian Luarte Leonel (Primavera do Leste/MT). The Peanut Breeding Program was supported by grants from Embrapa (SEG 02.12.010.00). 
BRS 425: the first runner peanut cultivar related to wild ancestral species

\section{REFERENCES}

Bertioli DJ, Cannon SB, Froenicke L, Huang G, Farmer AD, Cannon EKS, Liu X, Gao D, Clevenger J, Dash S, Ren L, Moretzsohn MC, Shirasawa K, Huang W, Vidigal B, Abernathy B, Chu Y, Niederhuth CE, Umale P, Araújo ACG, Kozik A, Kim KD, Burow MD, Varshney RK, Wang X, Zhang X, Barkley N, Guimarães PM, Isobe S, Guo B, Liao B, Stalker HT, Schmitz RJ, Scheffler BE, Leal-Bertioli SCM, Xun X, Jackson SA, Michelmore R and Ozias-Akins $P$ (2016) The genome sequences of Arachis duranensis and Arachis ipaensis, the diploid ancestors of cultivated peanut. Nature Genetics 47: 438-446.

Camelo-Garcia VM, Lima EFB, Mansilla-Córdova PJ, Rezende JAM, Kitajima EW and Barreto M (2014) Occurrence of groundnut ringspot virus on Brazilian peanut crops. Journal of General Plant Pathology 80 : 282-286.

Fávero AP, Simpson CE, Valls JFM and Vello NA (2006) Study of the evolution of cultivated peanut through crossability studies among Arachis ipaënsis, A. duranensis and A. hypogaea. Crop Science 46: 1546-1552.

Fonceka D, Tossim HA, Rivallan R, Vignes H, Faye I, Ndoye O, Moretzsohn MC, Bertioli DJ, Glaszmann JC, Courtois B and Rami JF (2012) Fostered and left behind alleles in peanut: interspecific QTL mapping reveals footprints of domestication and useful natural variation for breeding. BMC Plant Biology 12: 26-42.

Godoy IJ, Santos JF, Michelotto MD, Moraes ARA, Bolonhezi D, Freitas RS, Carvalho CRL, Finoto EL and Martins ALM (2017) IAC OL5 -
New high-oleic runner peanut cultivar. Crop Breeding and Applied Biotechnology 17: 289-292.

Leal-Bertioli SCM, Godoy IJ, Santos JF, Doyle JJ, Guimarães PM, Abernathy BL, Jackson SA, Moretzsohn MC and Bertioli DJ (2018) Segmental allopolyploidy in action: Increasing diversity through polyploid hybridization and homoeologous recombination. American Journal of Botany 105: 1-14.

Resende MDV (2016) Software Selegen-REML/BLUP: a useful tool for plant breeding. Crop Breeding and Applied Biotechnology 16: 330-339.

Resende MDV and Duarte JB (2007) Precisão e controle de qualidade em experimentos de avaliação de cultivares. Pesquisa Agropecuária Tropical 37: 182-194.

Sampaio RM (2016) Tecnologia e inovação: evolução e demandas na produção paulista de amendoim. Informações Econômicas 46: 27-42.

Suassuna TMF, Almeida MMS, Resende RO, Lima MGA, Faria JC and Suassuna ND (2016) Identificação de Tospovirus em amostras de amendoim com sintomas de clareamento das nervuras no estado de Goiás. In Bacha AL, Calixto AR, Braga AF, Cesarin AE, Silva BP, Braga IMRF, Santos JI, Carrega WC and Alves PLCA (eds) Anais do XIII Encontro sobre a cultura do amendoim. UNESP, Jaboticabal, p. 97-102.

Suassuna TMF, Suassuna ND, Moretzsohn MC, Leal-Bertioli SCM, Bertioli DJ and Medeiros EP (2015) Yield, market quality, and leaf spots partial resistance of interspecific peanut progenies. Crop Breeding and Applied Biotechnology 15: 1175-180. 